\title{
Myzostomida: a link between trochozoans and flatworms?
}

\author{
Igor Eeckhaut ${ }^{1 *}$, Damhnait McHugh ${ }^{2}$, Patrick Mardulyn ${ }^{3}$, Ralph Tiedemann $^{3}$, \\ Daniel Monteyne ${ }^{3}$, Michel Jangoux ${ }^{1,4}$ and Michel G. Milinkovitch ${ }^{3} \dagger$ \\ ${ }^{1}$ Marine Biology Laboratory, University of Mons, B-7000 Mons, Belgium \\ ${ }^{2}$ Department of Biology, Colgate University, Hamilton, NY 13346, USA \\ ${ }^{3}$ Unit of Evolutionary Genetics, Free University of Brussels, B-6041 Gosselies, Belgium \\ ${ }^{4}$ Marine Biology Laboratory, B-1050 Free University of Brussels, Belgium
}

\begin{abstract}
Myzostomids are obligate symbiotic invertebrates associated with echinoderms with a fossil record that extends to the Ordovician period. Due to their long history as host-specific symbionts, myzostomids have acquired a unique anatomy that obscures their phylogenetic affinities to other metazoans: they are incompletely segmented, parenchymous, acoelomate organisms with chaetae and a trochophore larva. Today, they are most often classified within annelids either as an aberrant family of polychaetes or as a separate class. We inferred the phylogenetic position of the Myzostomida by analysing the DNA sequences of two slowly evolving nuclear genes: the small subunit ribosomal RNA and elongation factor-1 $\alpha$. All our analyses congruently indicated that myzostomids are not annelids but suggested instead that they are more closely related to flatworms than to any trochozoan taxon. These results, together with recent analyses of the myzostomidan ultrastructure, have significant implications for understanding the evolution of metazoan body plans, as major characters (segmentation, coeloms, chaetae and trochophore larvae) might have been independently lost or gained in different animal phyla.
\end{abstract}

Keywords: Metazoa; Myzostomida; Annelida; evolution; molecular phylogeny; symbiosis

\section{INTRODUCTION}

Myzostomids (figure 1) form an enigmatic group of metazoans whose first described member was initially considered a new species of flatworm Trematoda based on its superficial external resemblance to flukes (Leuckart 1827, 1830, 1836). Since then, ca. 150 species have been described and grouped in a separate class, the Myzostomida. All are marine animals associated with echinoderms. Most are ectocommensals of crinoids but some species are ecto- or endoparasites of crinoids, asteroids or ophiuroids and infest the gonads, coelom, integument or digestive system of their host (Jangoux 1990). The association between myzostomids and echinoderms is very old as signs of parasitic activities similar to those induced by extant gallicolous myzostomids (i.e. those deforming echinoderm stereoms) are found on fossilized crinoid skeletons dating back to the Ordovician period (Warn 1974; Meyer \& Ausich 1983; Eeckhaut 1998). Due to their long history as host-specific symbionts, myzostomids have acquired a unique, highly derived anatomy (figure 1) that obscures their phylogenetic affinities to other metazoans. The body plan of most myzostomids is indeed singular as they are incompletely segmented, parenchymous, acoelomate organisms with chaetae (Von Graff 1884; Eeckhaut 1998) and exhibit a trochophore larva that appears early in their development (Eeckhaut \& Jangoux 1993).

Early assignments of myzostomids to the Trematoda (Leuckart 1827) and then to the Crustacea (Semper 1858)

\footnotetext{
*Author for correspondence (all aspects, igor.eeckhaut@umh.ac.be). $\dagger$ Author for correspondence

(phylogenetic aspects, mcmilink@ulb.ac.be).
}

or Stelechopoda (i.e. a taxon grouping myzostomids with the Tardigrada and Pentastomida) (Graff 1877) are no longer considered. Because myzostomids exhibit characters such as parapodia with chaetae, a trochophora-type larva and incomplete segmentation, they are classified in all textbooks and encyclopaedias as a family or an order of the Polychaeta or as a class of Annelida. Benham (1896) was the first to suggest them as a separate class of annelids (rather than as derived polychaete annelids), a position later supported by other investigators (e.g. Fedotov 1929; Kato 1952). Jägersten (1940) grouped the Myzostomida and the Annelida (as two separate classes) into a coelomate protostome clade called the Chaetophora. More recently, based on the ultrastructural similarities between the spermatozoa of the Myzostomida and Acanthocephala, Mattei \& Marchand (1987) considered these two taxa as sister groups defining a phylum that they called the Procoelomata. During the last four years, three cladistic analyses based on morphological characters have included data from the Myzostomida. In the first, Haszprunar (1996) concluded that the Myzostomida is a sister group of a clade including the Sipuncula, Echiura and annelids. On the other hand, Rouse \& Fauchald (1997) supported the placement of myzostomids as a family nested within the polychaete annelids. Finally, Zrzavy et al's (1998) analysis suggested that they are a sister group of a clade including the Echiura, Pogonophora and annelids.

Very little molecular data from myzostomids is available for phylogenetic scrutiny. Chenuil et al. (1997) sequenced a small part of the large ribosomal subunit RNA gene (LSU) of Myzostoma sp. and compared the secondary structure of this segment with that of other metazoans including polychaete and oligochaete annelids. No explicit analysis with 


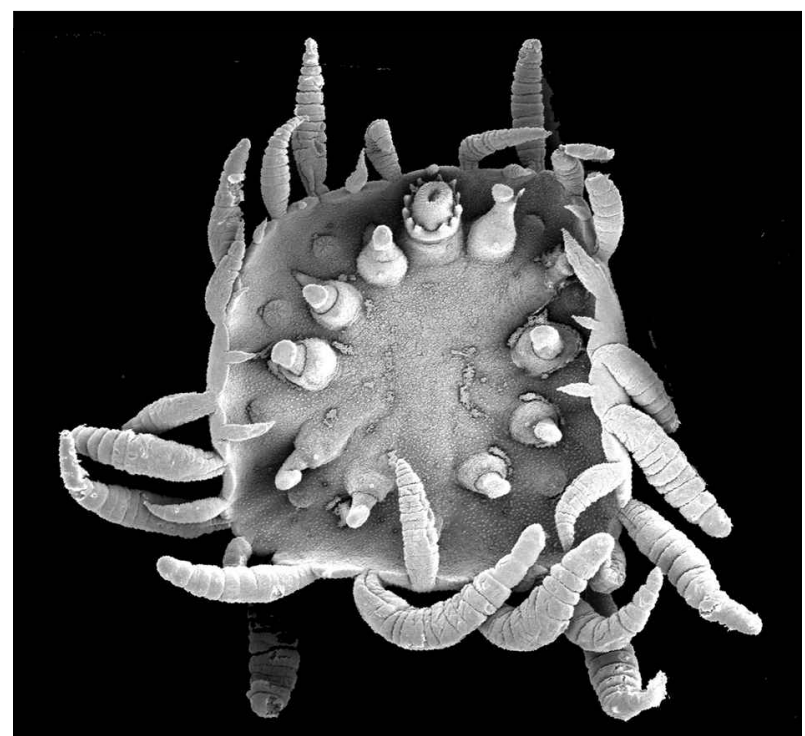

Figure 1. Scanning electron microscopy view of the ventral side of Myzostoma mortenseni, a myzostomid living on the feather star Clarkcomanthus albolineatus. The specimen shown is $1 \mathrm{~cm}$ long.

respect to the phylogenetic position of myzostomids was performed with these data. The small ribosomal subunit RNA gene $(S S U)$ has been widely used for estimating phylogenetic relationships between distantly related organisms (e.g. Field et al. 1988; Halanych et al. 1995; Winnepenninckx et al. 1995a,b, 1996, 1998; Mackey et al. 1996). Sequence data for this highly conserved gene are therefore available for a large number of species from many metazoan phyla (Hillis \& Dixon 1991). However, given that the $S S U$ is not a protein-coding gene and exhibits a relatively high heterogeneity in its nucleotide mutation rate across the gene sequence, alignment between sequences from distantly related species is often ambiguous, hence potentially precluding reliable phylogeny inference (McHugh 1998). Recently, slowly evolving protein-coding genes such as that coding for elongation factor-1 $\alpha(E F-1 \alpha)$ have been used for estimating deep phylogenetic relationships within the Metazoa (e.g. Kojima et al. 1993; Kobayashi et al. 1996; McHugh 1998).

We determined and phylogenetically analysed the nucleotide sequences of (i) the $S S U$ gene from five myzostomid species, and (ii) the expressed RNA of the $E F-1 \alpha$ gene from two other species. These sequences were analysed together with homologous sequences available from other metazoan taxa with special emphasis on testing the hypothesis of a monophyletic (Myzostomida + Polychaeta).

\section{MATERIAL AND METHODS}

(a) Species investigated and isolation and sequencing of the $\mathrm{SSU}$ and $\mathrm{EF}-1 \propto$ genes

The SSU gene sequences were obtained from five crinoidassociated myzostomid species: Cystimyzostoma clarki from Japan (host Metacrinus rotundus), Myzostoma cirriferum from France (host Antedon bifida) and Myzostoma fissum, Notopharyngoides aruense and Contramyzostoma sphaera from Papua New Guinea (hosts Dichrometra flagellata, Stephanometra oxyacantha and Comatella stelligera, respectively). The $E F-1 \alpha$ gene sequences were obtained from Myzostoma alatum and Pulvinomyzostomum pulvinar, both of which are associated with the Mediterranean crinoid Leptometra phalangium. The samples were preserved in $100 \%$ ethanol or in RNALater ${ }^{1}$. DNA was extracted following standard protocols and the SSU gene amplified by the polymerase chain reaction (PCR). RNA was isolated with TRIzol Reagent ${ }^{1}$ and the EF-1 $\alpha$ gene amplified by reverse transcriptase (RT)-PCR. Both strands of each of the two genes were sequenced on automated sequencers. The sequences determined for this study have been deposited at the EMBL database under accession numbers AF650584-AF650590. The alignments are available on request from the authors.

\section{(b) Alignment and phylogenetic analyses}

The myzostomid SSU sequences were aligned (ClustalX) (Thompson et al. 1994) to a set of metazoan sequences previously aligned according to a secondary structure model (Van de Peer et al. 1999), and the EF-1 $\alpha$ nucleotide sequences were aligned according to the corresponding amino-acid alignment performed with ClustalX. Two distinct sets of alignment parameters were used and positions at which the alignments differed were excluded in the subsequent analyses (Gatesy et al. 1993), except during searches under Goloboff (1993) weighting (see below). Each sequence in the $S S U+E F-1 \alpha$ data matrix consisted of concatenation of one $S S U$ and one $E F-1 \alpha$ sequence from individuals belonging to closely related taxa (i.e. most often the same species or genus) (see tables 1 and 2). Given the high computational burden of phylogenetic analysis and the high number of $S S U$ and $E F-1 \alpha$ sequences available, we were forced to choose two different samplings of ingroup taxa for investigating two different phylogenetic questions. In order to assess whether myzostomids would cluster within a specific group of annelids (i.e. the 'classical hypothesis'), we assembled a first set of ingroup taxa including all available myzostomid sequences and a large number of sequences representative of all major annelid groups (see table 1). The second set of ingroup taxa (table 2) included myzostomids and numerous invertebrates from various phyla in order to estimate the phylogenetic position of the former within the Spiralia. Six data matrices were thus analysed: the $S S U, E F-1 \alpha$ and $S S U+E F-1 \alpha$ matrices included myzostomid sequences as well as 22, 15 and five annelid sequences in the first set of ingroup taxa and 21, 22 and eight metazoan sequences in the second set of ingroup taxa, respectively (tables 1 and 2). Flatworms (first data set), Homo sapiens (for SSU and EF-1 $\alpha$, second data set) or two deuterostomes (for $S S U+E F-1 \alpha$, second data set) were used as outgroup taxa.

All maximum-parsimony (MP) analyses were performed with PAUP* (Swofford 1998, 1999) with exact branch-andbound searches (when computationally practical) or with the tree bisection-reconnection (TBR) swapping heuristic algorithm. All characters were first weighted equally and treated as unordered. However, it is now well known that different types of changes can occur at different evolutionary rates, which may, in specific cases, justify differential weighting (e.g. Milinkovitch et al. 1996; Swofford et al. 1996). We therefore checked for possible saturation of the nucleotide substitution types by plotting transversions $(\mathrm{Tv})$ versus transitions ( $\mathrm{Tr}$ ) as well as $\mathrm{Tr}$ and $\mathrm{Tv}$ versus pairwise distances. We also assessed the outcome of our unweighted analyses by excluding Tr or by using the Goloboff (1993) fit criterion with heuristic searches and $k=0,2,4$ and 8. We also estimated the influence of including or excluding ambiguous alignment positions (both genes) and inclusion or exclusion 
Table 1. List of the species (and accession numbers) used in the analyses with the Myzostomida and Annelida as the ingroup taxa

(The outgroup taxa were platyhelminth taxa: Notoplana koreana, Dugesia japonica and D. japonica + Dugesia mediterranea for the SSU, $E F-1 \alpha$ and $S S U+E F-1 \alpha$ data matrices, respectively. The species marked with an asterisk are those used during the ML searches.)

\begin{tabular}{|c|c|c|}
\hline$S S U$ & $E F-1 \alpha$ & $S S U+E F-1 \alpha$ \\
\hline $\begin{array}{l}\text { Myzostomida } \\
{ }^{*} \text { M. cirriferum (AF260585) } \\
\text { M. fissum (AF260584) } \\
\text { N. aruense (AF260587) } \\
{ }^{*} \text { C. clarki (AF260588) } \\
\text { C. sphaera (AF260586) }\end{array}$ & $\begin{array}{l}\text { Myostomida } \\
{ }^{*} \text { M. alatum (AF260590) } \\
\quad{ }^{*} \text { P. pulvinar (AF260589) }\end{array}$ & $\begin{array}{l}\text { Myzostomida } \\
{ }^{*} \text { M. cirriferum plus M. alatum } \\
{ }^{*} \text { C. clarki }+ \text { P. pulvinar }\end{array}$ \\
\hline $\begin{array}{l}\text { Annelida Achaeta } \\
\text { Glossiphonia } \mathrm{sp.} \text { (Z83751) } \\
{ }^{*} \text { Hirudo medicinalis (Z83752) } \\
\text { Sathodrilus attenuatus (Z83755) } \\
\quad \text { Xironogiton victoriensis (Z83756) }\end{array}$ & $\begin{array}{l}\text { Annelida Achaeta } \\
\quad \text { Myxobdella sinaensis (AB003716) } \\
\text { Haemadipsa zeylanica japonica (AB003717) } \\
\text { *H.medicinalis (HMU90063) }\end{array}$ & $\begin{array}{l}\text { Annelida Achaeta } \\
{ }^{*} H . \text { medicinalis }+H . \text { medicinalis }\end{array}$ \\
\hline $\begin{array}{l}\text { Annelida Oligochaeta } \\
\text { Aeolosoma sp. (Z83748) } \\
\text { Enchytraeus sp. (Z83750) } \\
{ }^{*} \text { Lumbricus rubellus (Z83753) } \\
\text { Stylaria } \text { sp. (U95946) } \\
{ }^{*} \text { Tubifex sp. (U67145) }\end{array}$ & $\begin{array}{l}\text { Annelida Oligochaeta } \\
{ }^{*} \text { Allolobophora } \mathrm{sp} .(\mathrm{AB} 003714) \\
\quad \text { Brachiura } \mathrm{sp} .(\mathrm{AB} 003715)\end{array}$ & $\begin{array}{l}\text { Annelida Oligochaeta } \\
\quad{ }^{*} \text { L. rubellus + Lumbricus terrestris } \\
\quad{ }^{*} \text { Tubifex sp. }+ \text { Brachiura } \mathrm{sp} .\end{array}$ \\
\hline 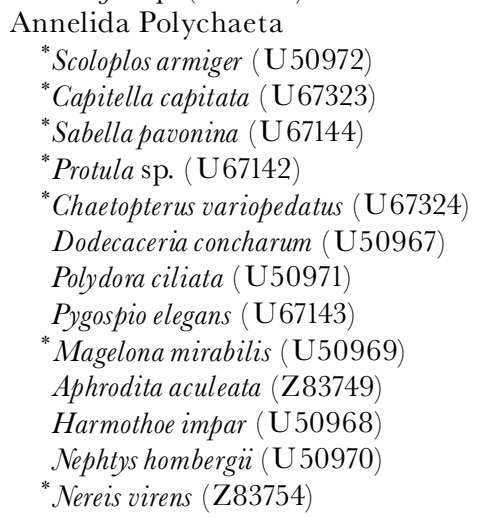 & $\begin{array}{l}\text { Annelida Polychaeta } \\
\quad{ }^{*} \text { Paralvinella hessleri (AB003711) } \\
{ }^{*} \text { Ampharetidae sp. (AB003712) } \\
{ }^{*} \text { Amphitrite sp. (AB003710) } \\
{ }^{*} \text { Laetmonicesp. (AB003703) } \\
\text { Hediste japonica (AB003702) } \\
{ }^{*} \text { N. virens (NV U90064) } \\
\quad{ }^{*} \text { Ophelina sp. (AB003708) } \\
\quad{ }^{*} \text { Eunice yamamotoi (AB003704) } \\
\quad{ }^{*} \text { Maldane cristata (AB003707) } \\
{ }^{*} \text { Owenia fusiformis (AB003709) }\end{array}$ & $\begin{array}{l}\text { Annelida Polychaeta } \\
{ }^{*} \mathcal{N} \text {. virens }+\mathcal{N} \text {. virens } \\
{ }^{*} \text { Capitella capitata }+ \text { M. cristata }\end{array}$ \\
\hline
\end{tabular}

of third nucleotide positions $(E F-1 \alpha)$ on the resulting inferred phylogeny.

The choice of outgroup taxa can alter the placement of the root under both the MP and maximum-likelihood (ML) criteria (e.g. Wheeler 1990; Milinkovitch et al. 1996), and also the optimal topology of the ingroup tree (Milinkovitch \& Lyons-Weiler 1998). We therefore investigated the effect of outgroup choice on the outcome of our analyses with the first set of ingroup taxa (table 1) by testing each of the 29 outgroup taxa belonging to the Diploblastica (six taxa), Platyhelminthes (i.e. flatworms) (five taxa), Mollusca (three taxa), Arthropoda (five taxa) and Deuterostomia (ten taxa).

We estimated the reliability of the various inferred phylogenetic nodes by bootstrapping $\left(10^{3}-10^{4}\right.$ replicates for MP and neighbour joining (NJ) and 100-400 replicates for $\mathrm{ML}$ ) (Felsenstein 1985), although bootstrap values (BVs) may be misleading estimates of accuracy under specific conditions (Lecointre et al. 1993; Milinkovitch et al. 1996). We computed Bremer (1994) branch support (BS), i.e. the number of additional character transformations necessary to collapse an internal branch, as an alternative to $\mathrm{BV}$ s for estimating the clade stability for selected branches and using the 'constraints' command in PAUP*. We also performed cladistic permutation tail probability (PTP) and topology-dependent PTP (T-PTP) (Faith 1991; Faith \& Trueman 1996) analyses to compare alternative phylogenetic hypotheses statistically. Using a priori T-PTP for evaluating various clades is valid because we only used the method for testing the phylogenetic hypotheses formulated prior to any analysis with the present data.

We used PAUP* heuristic searches in order to estimate ML trees with the following settings: nucleotide frequencies computed from the data, the proportion of invariable sites and the $\mathrm{Tv} / \mathrm{Tr}$ ratio estimated via ML, the rates for variable sites assumed to follow a gamma distribution with the shape parameter estimated by ML (four rate categories with the average rate represented by the mean), the HKY 85 model (Hasegawa et al. 1985) with rate heterogeneity and TBR branch swapping. Alternative phylogenetic hypotheses were compared statistically by means of the Templeton (1983) (MP) and Kishino \& Hasegawa (1989) (KH) ML ratio tests. NJ analyses were performed with PAUP*.

Several types of systematic biases, which can mislead phylogenetic analysis, may be present in molecular sequence data. We performed different tests in order to check whether our results were influenced by biases identified as potentially misleading in previous studies.

(i) NJ analyses were performed using LogDet distances (Lockhart et al. 1994), which were calculated after removing different proportions of the invariable sites in 
Table 2. List of the species (and accession numbers) used in the analyses with the Myzostomida and other Metazoa as the ingroup taxa

(The outgroup taxa were Homosapiens (Vertebrata) for both the SSU and EF-1 $\alpha$ data matrices. In addition to the H.sapiens sequences, we also used a 'hybrid' sequence consisting of the concatenation of the SSU sequence from a fish (Notorynchus cepedianus) and the EF-1 $\alpha$ sequence from an amphibian (Xenopus laevis) as part of the outgroup for the combined $S S U+E F-1 \alpha$ data matrix. This procedure is valid given the near certainty of vertebrate monophyly. The species marked with an asterisk are those used during the ML searches.)

\begin{tabular}{|c|c|c|}
\hline$S S U$ & $E F-1 \alpha$ & $S S U+E F-1 \alpha$ \\
\hline $\begin{array}{l}\text { Myzostomida } \\
{ }^{*} \text { M. cirriferum } \\
\text { M. fissum } \\
\text { N. aruense } \\
{ }^{*} \text { C. clarki } \\
\quad \text { C. sphaera }\end{array}$ & $\begin{array}{l}\text { Myzostomida } \\
{ }^{*} \text { M. alatum } \\
{ }^{*} \text { P. pulvinar }\end{array}$ & $\begin{array}{l}\text { Myzostomida } \\
{ }^{*} \text { M.cirriferum }+ \text { M. alatum } \\
\quad{ }^{*} \text { C. clarki }+ \text { P. pulvinar }\end{array}$ \\
\hline $\begin{array}{l}\text { Platyhelminthes (flatworms) } \\
\text { Fasciolopsis buski (L06668) } \\
{ }^{*} \text { D. mediterranea }(\mathrm{M} 58344) \\
\text { Otoplana } \text { sp. (D85090) } \\
{ }^{*} \text { N. koreana }(\mathrm{D} 85097)\end{array}$ & $\begin{array}{l}\text { Platyhelminthes } \\
\quad{ }^{*} \text { D. japonica }(\mathrm{DJAEF} 1 \mathrm{AG})\end{array}$ & $\begin{array}{l}\text { Platyhelminthes } \\
\quad{ }^{*} D . \text { mediterranea }+D \text {. japonica }\end{array}$ \\
\hline $\begin{array}{l}\text { Mollusca } \\
\quad \text { Helix aspersa (X91976) } \\
\text { Littorina littorea (X91970) } \\
{ }^{*} \text { Mytilus edulis (L24489) }\end{array}$ & $\begin{array}{l}\text { Mollusca } \\
{ }^{*} \text { Turbo cornutus (AB003720) }\end{array}$ & $\begin{array}{l}\text { Mollusca } \\
\quad{ }^{*} \text { H. aspers } a+\text { T. cornutus }\end{array}$ \\
\hline $\begin{array}{l}\text { Pogonophora } \\
\quad \text { *Siboglinum fiordicum (X 79876) }\end{array}$ & $\begin{array}{l}\text { Pogonophora } \\
\quad{ }^{*} \text { Lamellibrachia sp. (AB003721) } \\
\quad \text { Escarpiasp. (AB003718) }\end{array}$ & $\begin{array}{l}\text { Pogonophora } \\
\quad \text { *S. fiordicum + Lamellibrachia sp. }\end{array}$ \\
\hline $\begin{array}{l}\text { Arthropoda } \\
{ }^{*} \text { Tenebrio molitor (X07801) } \\
\quad \text { Artemia salina }(\mathrm{X} 01723)\end{array}$ & $\begin{array}{l}\text { Arthropoda } \\
\quad \text { Hanseniella sp. (AB003712) } \\
{ }^{*} \text { Dysdera crocata (DCU90047) } \\
\text { Symmerista albifrons (SAU85667) } \\
\text { Heliocheilus albipunctella (HAU20127) }\end{array}$ & $\begin{array}{l}\text { Arthropoda } \\
{ }^{*} \text { Tenebrio molitor }+ \text { Symmerista } \mathrm{sp} .\end{array}$ \\
\hline $\begin{array}{l}\text { Annelida } \\
\text { Glossiphonia } \mathrm{sp} .(\mathrm{Z} 83751) \\
{ }^{*} \text { H. medicinalis }(\mathrm{Z} 83752) \\
{ }^{*} \text { L. rubellus }(\mathrm{Z} 83753) \\
\text { Tubifex } \mathrm{sp} .(\mathrm{U} 67145) \\
\text { A. aculeata }(\mathrm{Z} 83749) \\
{ }^{*} \text { N. virens }(\mathrm{Z} 83754)\end{array}$ & $\begin{array}{l}\text { Annelida } \\
{ }^{*} \text { Allolobophorasp. (AB003714) } \\
\quad \text { Brachiura sp. (AB003715) } \\
\text { M. sinaensis (AB003716) } \\
\text { H. z. japonica (AB003717) } \\
{ }^{*} \text { H. medicinalis (HMU90063) } \\
\quad{ }^{*} \text { Paralvinella hessleri (AB003711) } \\
\text { Ampharetidae sp. (AB003712) }\end{array}$ & $\begin{array}{l}\text { Annelida } \\
\quad{ }^{*} \text { Tubifex } \mathrm{sp} .+ \text { Brachiura } \mathrm{sp} . \\
\quad{ }^{*} \text { H. medicinalis }+ \text { H. medicinalis } \\
{ }^{*} \mathcal{N} . \text { virens }+\mathcal{N} \text {. virens } \\
{ }^{*} \text { C. capitata }+ \text { M. cristata }\end{array}$ \\
\hline $\begin{array}{l}\text { Sipuncula } \\
\quad{ }^{*} \text { Phascolosoma granulatum (X79874) } \\
\text { Echiura } \\
\quad{ }^{*} \text { Ochetostoma erythrogrammon (X79875) } \\
\text { Acanthocephala } \\
\quad \text { Macracanthorhynchus ingens (AF001844) } \\
{ }^{*} \text { Neoechinorhynchus crassus (AF001842) } \\
\text { Centrorhynchus conspectus (U41399) }\end{array}$ & $\begin{array}{l}\text { Amphitritesp. (AB003710) } \\
\text { Laetmonicesp. (AB003703) } \\
\text { H.japonica (AB003702) } \\
{ }^{*} \text { N. virens (NVU90064) } \\
{ }^{*} \text { Ophelina } \mathrm{sp} .(\mathrm{AB} 003708) \\
\text { E.yamamotoi (AB003704) } \\
\text { M. cristata }(\mathrm{AB} 003707) \\
\text { O. fusiformis (AB003709) }\end{array}$ & \\
\hline
\end{tabular}

order to correct for possible differences in the base composition between lineages.

(ii) We tested for the presence of covarion-covariotide structure in the data (i.e. differences in the distribution of invariable sites between lineages) using an inequality test (Lockhart et al. 1998).

(iii) Simulation analyses (Huelsenbeck 1997) were performed on the $S S U+E F-1 \alpha$ data in order to ensure that the phylogenetic position of the myzostomids within the metazoans is not the result of the so-called 'long-branch attraction' artefact (Felsenstein 1978; Hendy \& Penny 1989).

In order to investigate their evolution, four important Spiralian characters (coeloms, chaetae, trochophores and segmentation) were mapped onto the optimal phylogenetic trees obtained with the $S S U+E F-1 \alpha$ data matrix including myzostomids and other metazoans using MacClade 3.0 (Maddison \& Maddison 1992).

\section{RESULTS}

After alignment (default settings) the resulting SSU and $E F-1 \alpha$ matrices were of 2470 and 1398 characters, respectively.

\section{(a) Are myzostomids nested within annelids?}

Using the first set of ingroup taxa (table 1), the MP, ML and NJ analyses of $S S U$ and $E F-1 \alpha$, as well as a combination of both loci $(S S U+E F-1 \alpha)$, all yielded best trees with the Myzostomida not nested within the Annelida. This result was stable to analytical variations 


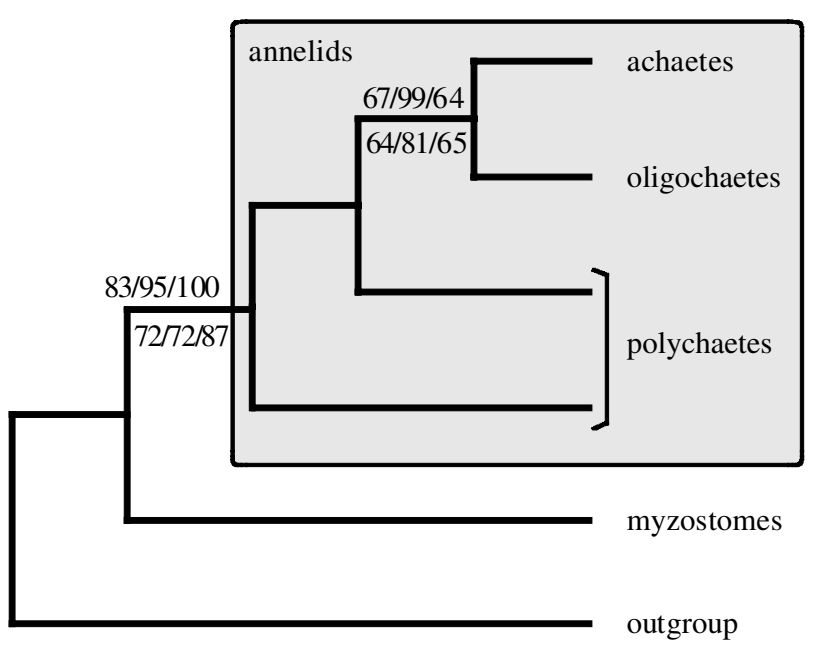

Figure 2. Myzostomids are not annelids. A cladogram summarizing the results obtained with the first set of ingroup taxa (i.e. myzostomids and annelids) (see table 1). This cladogram is compatible with all the NJ, MP and ML trees obtained with the $S S U, E F-1 \alpha$ and $S S U+E F-1 \alpha$ data matrices (the outgroup taxa were the flatworm species $\mathcal{N}$. koreana, $D$.japonica and D.japonica plus D. mediterranea, respectively). The BVs ( $10^{3}$ replicates) for the $S S U, E F-1 \alpha$ and $S S U+E F-1 \alpha$ data matrices are indicated above and below the branches for NJ and MP, respectively.

such as Goloboff (1993) weighting and substitution-type weighting, and was strongly supported by bootstrapping (figure 2): the exclusion of myzostomids from the annelids was found in 83, 95 and $100 \%(\mathrm{NJ})$ and 72, 72 and $87 \%$ (MP) of the 1000 bootstrap replicates for $S S U, E F-1 \alpha$ and $S S U+E F-1 \alpha$, respectively. Furthermore, the T-PTP results indicated significant support for the monophyly of the annelids to the exclusion of the myzostomids ( $p<0.05$ with each of the three data matrices). Within the Annelida, the Polychaeta are found to be paraphyletic with respect to the monophyletic Clitellata (achaetes + oligochaetes) as suggested in previous molecular (e.g. Kim et al. 1996; Kojima 1998; Winnepenninckx et al. 1998) and morphological studies (Westheide 1997).

The grouping of the four comatulid crinoid-associated species was strongly supported within the Myzostomida (figure 3). The European M. cirriferum is separated from the three Indo-Pacific myzostomids within that group and the two endoparasites C. sphaera and $\mathcal{N}$. aruense group to the exclusion of the ectocommensal M.fissum (figure 3).

\section{(b) Phylogenetic affinities of myzostomids with other metazoans}

Saturation plots (data not shown) indicated no obvious $\mathrm{Tr}$ or $\mathrm{TV}$ saturation for the whole range of pairwise distances.

With the second set of ingroup taxa, the analyses under MP, ML and NJ for EF-1 $\alpha$ (regardless of the inclusion or exclusion of third codon positions) and under NJ for SSU all suggested a surprising grouping of myzostomids and flatworms in a clade (figure 4). The MP and ML analyses of SSU alone yielded best trees with the Myzostomida within a clade including the Arthropoda and Acanthocephala in addition to the Platyhelminthes. However, under the Templeton (MP) and KH (MP and ML) tests, these
$S S U$ trees were not significantly better than trees where a clade comprised exclusively of myzostomids and flatworms was constrained, while they were significantly better $(p<0.05)$ than constrained trees grouping the myzostomids with the annelids (i.e. the classical hypothesis).

All of the MP, NJ and ML analyses of the combined $S S U+E F-1 \alpha$ data set, including the bootstrap analyses, supported a myzostomids + flatworms clade. Because of the high computational intensity of ML estimations, the bootstrap analysis using the ML criterion was performed with constraining ML parameter values to those obtained in the single ML search with the same taxon sampling. Figure 5 shows the ML phylogram obtained from the analysis of the combined data set $(-\ln L=17846.57572)$. The grouping of the myzostomids and flatworms was supported by high bootstrap values (98, 100 and 93\% for NJ, MP and ML, respectively) and was stable to analytical variations such as Goloboff (1993) weighting, substitution-type weighting and the exclusion of the third codon position. A myzostomids + annelids clade occurred in none of the $10^{4} \mathrm{MP}$ and $200 \mathrm{ML}$ bootstrap replicates. Constraining in order not to keep a monophyletic myzostomids + flatworms clade requires a significant decrease in log-normal likelihood by the KH test $(p<0.05)$. This means that any tree not containing that clade is significantly less likely than the ML tree shown in figure 5 . Constraining the grouping of myzostomids with annelids significantly decreased the log-normal likelihood $(p<0.05)$. The second major node indicated in figure 5 (i.e. arthropods + molluscs + pogonophores + annelids) was found in 100, 87 and $64 \%$ of the bootstrap replicates for NJ, MP and ML, respectively. The partial lack of resolution within that clade is due to (i) our conservative choice of indicating only the nodes supported by high $\mathrm{BVs}$, and (ii) conflicting signals from SSU and EF-1 $\alpha$. On the other hand, the grouping of the myzostomids with the annelids was congruently and very strongly rejected by the two genes and the analyses of the combined data sets strongly supported the grouping of myzostomids and flatworms. Analyses constraining the monophyly of (i) myzostomids + annelids, (ii) myzostomids + annelids but enabling other taxa to fit in between (i.e. the 'backbone constraint' in PAUP*) or (iii) flatworms + an outgroup (i.e. two deuterostomes) all yielded trees that were significantly worse $(p<0.005, \quad p<0.001$ and $p=0.05$ for MP Templeton, MP KH and ML KH tests, respectively) than the best tree, i.e. displaying a myzostomids + flatworms clade. Under the MP criterion, as many as 73 additional evolutionary events are needed to join the myzostomids and annelids in a monophyletic group (combined data matrix).

The results of the inequality test performed on the $S S U$ $+E F-1 \alpha$ data matrix suggested that there are no significant differences in the distribution of invariable sites between lineages. Furthermore, our simulation analyses based on the Huelsenbeck (1997) method indicated that the myzostomids + flatworms clade is unlikely to be the result of a long-branch attraction artefact. Indeed, starting with the MP tree in which the myzostomid lineage was attached to the flatworm branch, new trees were obtained by reassigning the position of the myzostomid lineage on each of the other 19 branches. One 


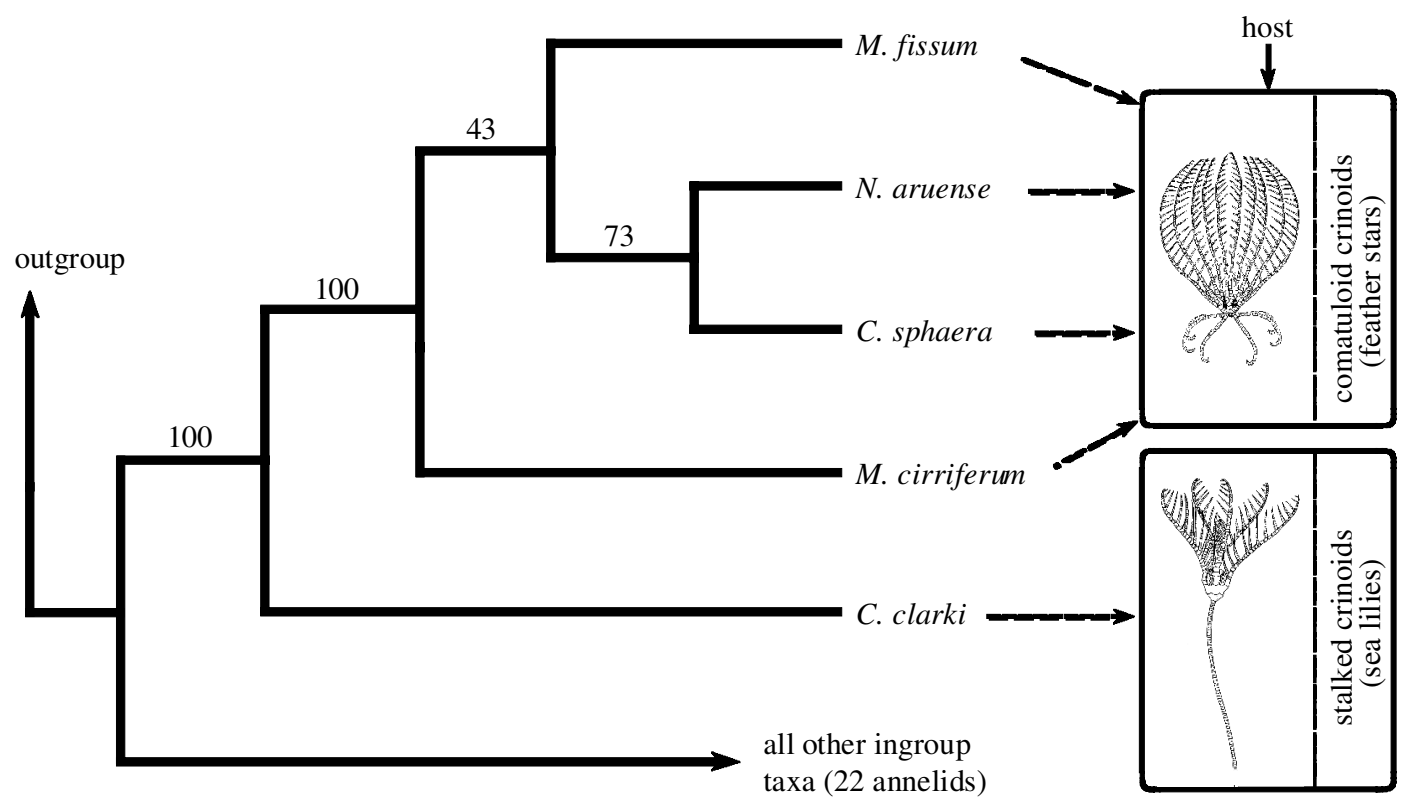

Figure 3. Close up of the Myzostomida clade within the strict consensus among the six equally parsimonious trees (tree length $=1359)\left(S S U\right.$ data matrix with five Myzostomida and 22 Annelida as ingroup taxa) (cf. table 1). The BVs (10 ${ }^{4}$ replicates) are indicated on the branches. For each sequenced myzostomid species the dotted arrows indicate the type of crinoids it infests.

hundred data sets were simulated with SequenceGenerator (v. 1.1) (Rambaut \& Grassly 1997) for each of these 19 'model trees' using an HKY85 model of evolution (Hasegawa et al. 1985) with site-specific rate heterogeneity. The parameters of this model (branch lengths, $\operatorname{Tr} / \mathrm{Tv}$ ratio, proportion of invariable sites and shape parameter of the gamma distribution) were estimated from the original data set for each model tree using the likelihood criterion. A parsimony analysis was performed for each of the 19 model trees on each of the 100 simulated data sets. Twelve model trees yielded a majority of data sets supporting (in MP analyses) the same placement of the myzostomids than in the corresponding model tree. This indicates that, even in MP analyses, the myzostomid and flatworm branches are not sufficiently long to attract if one of these model trees corresponds to the true tree. On the other hand, seven model trees yielded a majority of data sets supporting (in a MP analysis) a clade comprising myzostomids and flatworms. This suggests that, if one of these seven model trees is correct, the myzostomid and flatworm branches are long enough to attract in a parsimony analysis. However, the possibility of long-branch attraction for these simulated data sets was lifted when they were subjected to a ML analysis identical to the one performed on the real sequence data. Therefore, these simulations indicated that the myzostomids + flatworms clade, which was strongly supported by the ML analysis of our sequence data was unlikely to be the result of a long-branch attraction artefact.

The inclusion of Acanthocephala sequences was only possible for $S S U$ and the grouping of this taxon with mysostomes was not supported by either the NJ, MP or ML analyses.

\section{DISCUSSION}

Three recent, alternative and mutually exclusive hypotheses have been formulated concerning the phylogenetic position of the Myzostomida: (i) they are included within the group of polychaete annelids (Rouse \& Fauchald 1997), (ii) they are closely related to the Acanthocephala (Mattei \& Marchand 1987) or (iii) they are included within the Trochozoa but excluded from the Annelida (Haszprunar 1996; Zrzavy et al. 1998). Each of these hypotheses will be discussed in turn below.

(i) Our analyses strongly reject the grouping of myzostomids with any subgroup of annelids. This does not really conflict with morphological data because, although myzostomids are most often considered as polychaete annelids, not a single morphological synapomorphy (i.e. a shared derived character state) linking the two taxa has been unambiguously identified. Indeed, the character states usually put forward for grouping myzostomids and polychaetes (the presence of chaetae and a trochophore larva) are encountered in other spiralian groups: chaetae occur in the Clitellata, Pogonophora, Echiura, and some Mollusca and Brachiopoda (Specht 1988), and trochophores are found in the development of some Mollusca, Sipuncula, Echiura and Pogonophora (Heimler 1987). Two other characters are often cited as supporting the grouping of myzostomids with the Polychaeta: the presence of a segmented body and a coelom. Although most myzostomids undoubtedly show some signs of segmentation (they have serial paired external appendages and/or organs) (cf. figure 1 and serial protonephridia), all extant myzostomids could very well be, strictly speaking, acoelomate organisms (Eeckhaut 1995; Haszprunar 1996). Indeed it is doubtful whether the myzostomidan female gonads evolved from large annelid-like coelomic cavities. The main argument supporting the coelomic origin of these structures was the observation of female germinal cells developing in a cavity bordered by a 'coelomic-like' epithelium 


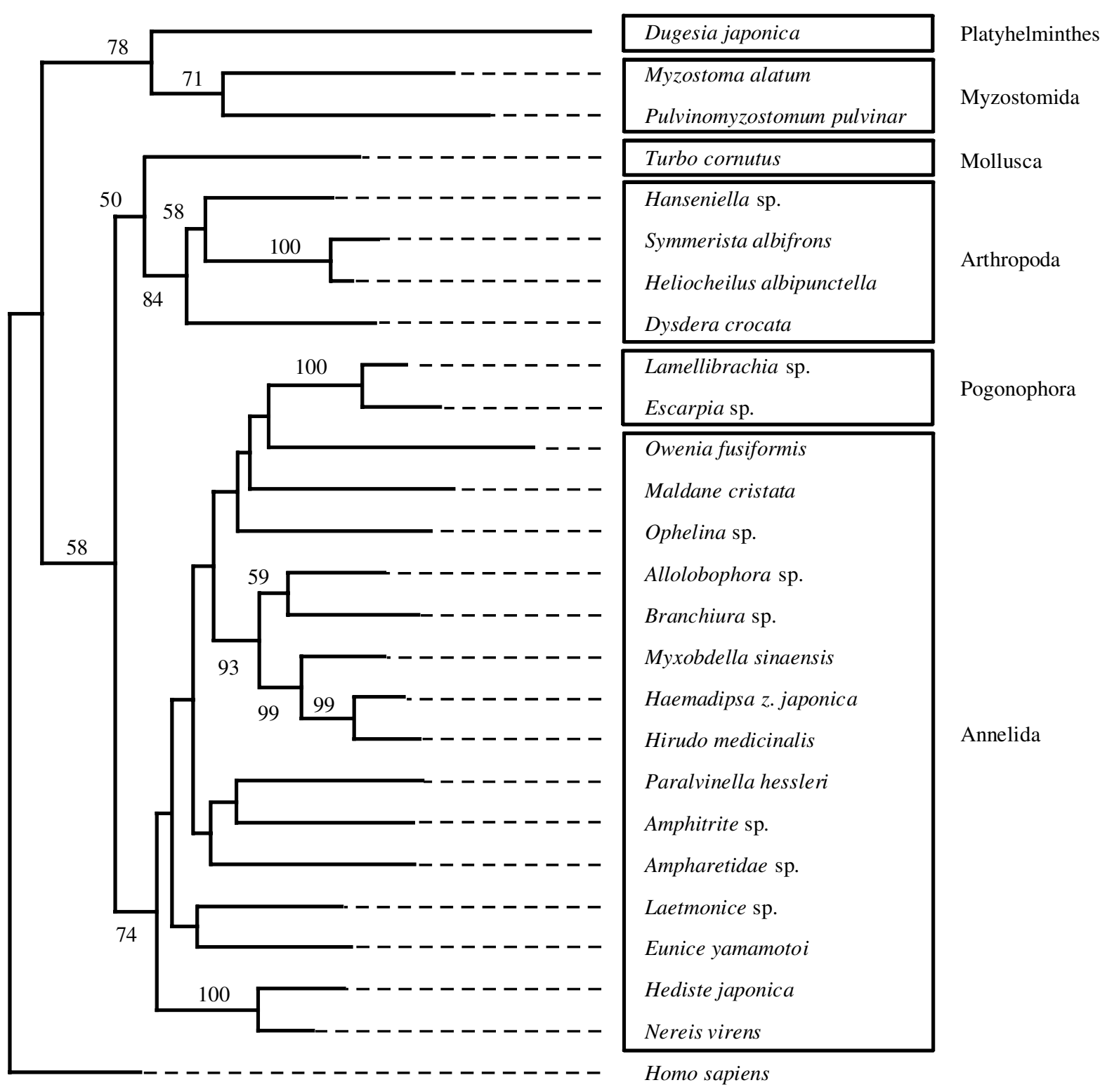

Figure 4. ML phylogram obtained from the analysis of the $E F-1 \alpha$ data set. BVs $>50 \%$ are shown.

(Jägersten 1940). However, recent ultrastructural investigations have shown that female germinal cells in myzostomids develop within the parenchyma and not in a coelomic cavity (Eeckhaut 1995).

(ii) Our molecular phylogenetic analyses do not support the sister relationship between myzostomids and acanthocephalans (even though they are more related to each other than they are to annelids) (SSU tree, data not shown) proposed by Mattei \& Marchand (1987) on the basis of ultrastructural sperm cell similarities between the two groups. Acanthocephalans form a phylum of $c a .1150$ species of parasitic, worm-like aschelminths and, indeed, as do myzostomids, exhibit sperm cells with idiosyncratic attributes such as an anterior flagellum that pulls the cell forwards, cytoplasmic processes that attach the posterior part of the flagellum along the whole cell body and a nucleocytoplasm including heterochromatin and proteinic granules (Afzelius 1983, 1984; Mattei \& Marchand 1987). The spermatogenesis in both groups is also roughly similar (Afzelius 1984; Mattei \& Marchand 1987). Although the value of the sperm cell ultrastructure has been suggested for estimating organism phylogenies for many invertebrate groups (Erséus \& Ferraguti 1995; Justine 1995; Healy 1996), our analyses indicated that these features are not phylogenetically informative in inferring the position of myzostomids within metazoans.

(iii) Our molecular phylogenetic analyses not only supported the idea that myzostomids are excluded from the Annelida but additionally suggested the surprising hypothesis that they are more closely related to flatworms than to annelids or to any other taxon. Our results sound less provocative in the light of recent molecular studies. Indeed, it has been suggested (Aguinaldo \& Lake 1998; Balavoine 1998; Garey \& Schmidt-Rhaesa 1998) that the Platyhelminthes are not basal within the Triploblastica clade but rather form a derived group within the Spiralia, 


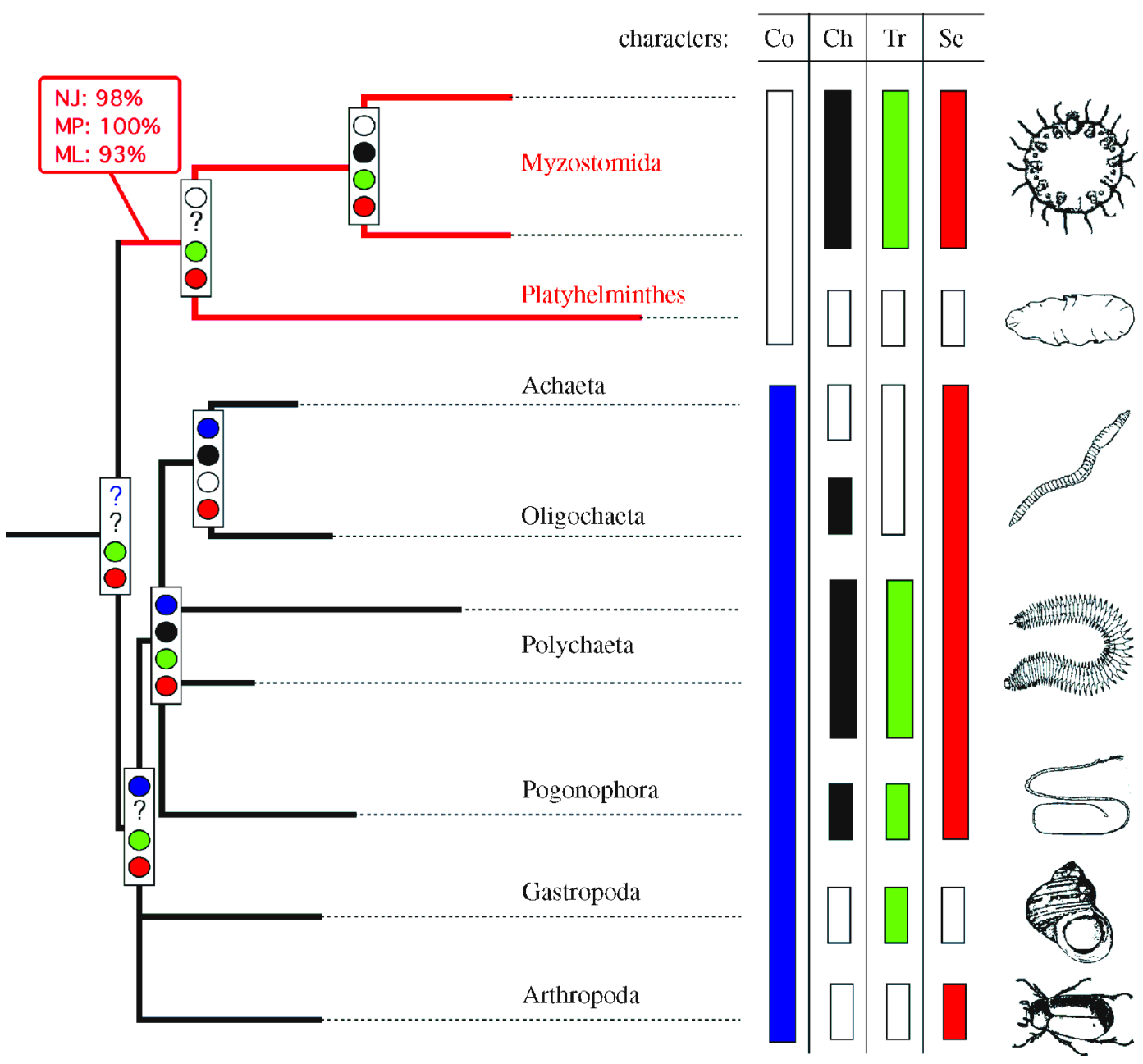

Figure 5. Myzostomida are not Annelida but a sister group to the Platyhelminthes (i.e. flatworms). The tree shown is the ML tree obtained from the analysis of the combined $S S U$ and $E F-1 \alpha$ genes (i.e. including the taxa for which both gene sequences are available). Nodes supported by ML BVs $<50 \%$ are collapsed. The boxed numbers indicate the BVs for the myzostomids + flatworms clade (1000 replicates for NJ and MP and 400 replicates for ML). The second major clade (myzostomids + flatworms + annelids + pogonophores + molluscs + arthropods) is supported by BVs of 100, 87 and 64\% for NJ, MP and ML, respectively. The presence of a coelom (Co), chaetae (Ch), a trochophore larva ( Tr) and segmentation (Se) in extant taxa is indicated by blue, black, green and red vertical bars, respectively. Blank bars correspond to the absence of the corresponding character. MP reconstructions of the ancestral character states are indicated for each node with dots of the corresponding colour. Question marks indicate that both the presence and absence of the character are equally parsimonious.

hence suggesting that extant acoelomates arose from a coelomate ancestor. Accordingly, the placement of the Myzostomida as a sister group to the Platyhelminthes implies that major characters found in the former, such as chaetae, trochophore larvae and segmentation, are either convergent with those found in trochozoan phyla or ancestral within the Spiralia. Ultrastructural investigations of the chaetae and trochophore larvae of myzostomids have indicated that these characters are probably homologous to those found in annelids (Heimler 1987; Specht 1988). Furthermore, homology between the segmentation of myzostomids and annelids has been recently suggested by the discovery of serial nephridia in the former (Pietsch \& Westheide 1987). Inference of the ancestral state for these characters is a very difficult endeavour because it depends on the respective likelihoods of gains and losses of complex structures. If one considers the relatively conventional hypothesis that multiple losses of complex characters are more likely than their multiple and independent gains (e.g. Dollo 1893; Omland 1999), our results would then suggest that the common ancestor of flatworms, myzostomids and trochozoans was a segmented worm-like organism with chaetae whose development included a trochophore larval stage. However, under equal probabilities of gains and losses, all of the most parsimonious reconstructions of the four characters (coeloms, chaetae, trochophores and segmentation) (figure 5) suggest that the ancestor of the ingroup taxa was indeed segmented and had a trochophore larva but the most parsimonious ancestral state for the two remaining characters (coeloms and chaetae) cannot be resolved unambiguously. Regardless of the exact morphology of the common ancestor of flatworms, myzostomids and trochozoans, our results have important implications in evolutionary biology and comparative 
morphology because they demonstrate that the major characters used for the classification of the Metazoa (e.g. segmentation, the presence-absence of a coelom and the presence-absence of a specific larval stage) are not as conservative and noise free as is generally implied: these characters would have experienced multiple independent reversals or convergences among different phyla.

We are indebted to Professor T. Oji who sent us specimens of C. clarki. Thanks to Professor Frontier, director of the Observatoire Océanologique de Roscoff (France) for providing facilities in the station where some myzostomids were sampled. The National Fund for Scientific Research, Belgium (FRFC 2.4508 $\&$ 2.4560), provided substantial support for this work. M.C.M. was also supported by the Free University of Brussels (ULB), the Defay Fund, the Communauté Française de Belgique (ARC 98/03-223) and the Van Buuren Fund. This research is a contribution of the Centre Interuniversitaire de Biologie Marine (CIBIM). P.M. is a research associate at the National Fund for Scientific Research, Belgium.

\section{REFERENCES}

Afzelius, B. A. 1983 The spermatozoon of Myzostomum cirriferum (Annelida, Myzostomida). F. Ultrastruct. Res. 83, 58-68.

Afzelius, B. A. 1984 Spermiogenesis in Myzostomum cirriferum (Annelida, Myzostomida). Vidensk. Meddr Dansk Naturh. Foren. $145,11-21$.

Aguinaldo, A. M. A. \& Lake, J. A. 1998 Evolution of the multicellular animals. Am. Zool. 38, 878-887.

Balavoine, G. 1998 Are Platyhelminthes coelomates without coelom? An argument based on the evolution of Hox genes. Am. Zool. 38, 843-858.

Benham, W. B. 1896 Archiannelida, Polychaeta, Myzostomidaria. In The Cambridge natural history (ed. S. F. Farmer \& A. E. Shipley), pp. 241-334. London: Macmillan.

Bremer, K. 1994 Branch support and tree stability. Cladistics 10, 295-304.

Chenuil, A., Solignac, M. \& Bernard, M. 1997 Evolution of the large-subunit ribosomal RNA binding site for protein L23/25. Mol. Biol. Evol. 14, 578-588.

Dollo, L. 1893 Les Lois de l'Evolution. Bull. Soc. Belge Geol. Pal. Hydr. 7, 164-166.

Eeckhaut, I. 1995 Cycle vital et biologie de Myzostoma cirriferum (Myzostomida), symbiote obligatoire de la comatule Antedon bifida (Echinodermata). PhD thesis, Université de MonsHainaut, Belgium.

Eeckhaut, I. 1998 Mycomyzostoma calcidicola gen. nov., sp. nov., the first extant parasitic myzostomid infesting crinoid stalks, with a nomenclatural appendix by M. J. Grygier. Species Divers. 3, 89-103.

Eeckhaut, I. \& Jangoux, M. 1993 Life cycle and mode of infestation of Myzostoma cirriferum (Annelida), a symbiotic myzostomid of the comatulid crinoid Antedon bifida (Echinodermata). Dis. Aquat. Org. 15, 207-217.

Erséus, C. \& Ferraguti, M. 1995 The use of spermatozoal ultrastructure in phylogenetic studies of Tubificidae (Oligochaeta). In Advances in spermatozoal phylogeny and taxonomy (ed. B. G. M. Jamieson, J. Ausio \& J. L. Justine), pp. 189-202. Paris: Mémoires du Muséum National d'Histoire Naturelle.

Faith, D. P. 1991 Cladistic permutation tests for monophyly and nonmonophyly. Syst. Zool. 40, 366-375.

Faith, D. P. \& Trueman, J. W. H. 1996 When the topologydependent permutation test (T-PTP) for monophyly returns significant support for monophyly, should that be equated with (a) rejecting a null hypothesis of nonmonophyly, (b) rejecting a null hypothesis of 'no structure', (c) failing to falsify a hypothesis of monophyly, or (d) none of the above? Syst. Biol. 45, 580-586.

Fedotov, D. 1929 Beiträge zu Kenntnis der Morphologie der Myzostomiden. Zeitschr. Morphol. Okol. Der Tiere 15, 156-191.

Felsenstein, J. 1978 Cases in which parsimony and compatibility methods will be positively misleading. Syst. Zool. 27, 401-410.

Felsenstein, J. 1985 Confidence limits on phylogenies: an approach using the bootstrap. Evolution 39, 783-791.

Field, K. J., Olsen, G. J., Lane, D. J., Giovannoni, S. J., Ghiselin, M. T., Raff, E. C., Pace, N. R. \& Raff, R. A. 1988 Molecular phylogeny of the animal kingdom. Science 239, 748-753.

Garey, J. R. \& Schmidt-Rhaesa, A. 1998 The essential role of 'minor' phyla in molecular studies of animal evolution. $\mathrm{Am}$. Zool. 38, 907-917.

Gatesy, J., DeSalle, R. \& Wheeler, W. 1993 Alignmentambiguous nucleotide sites and the exclusion of systematic data. Mol. Phylogenet. Evol. 2, 152-157.

Goloboff, P. A. 1993 Estimating character weights during tree search. Cladistics 9, 83-91.

Graff, L. 1877 Das Genus Myzostoma (F. S. Leuckart). Leipzig, Germany: Wilhelm Engelmann.

Halanych, K. M., Bacheller, J. D., Aguinaldo, A. M. A., Liva, S. M., Hillis, D. M. \& Lake, J. A. 1995 Evidence of 18S ribosomal DNA that the lophophorates are protostome animals. Science 267, 1641-1643.

Hasegawa, M., Kishino, H. \& Yano, T. 1985 Dating of the human-ape splitting by a molecular clock of mitochondrial DNA. F. Mol. Evol. 22, 160-174.

Haszprunar, G. 1996 The Mollusca: coelomate turbellarians or mesenchymate annelids? In Origin and evolutionary radiation of the Mollusca (ed. J. D. Taylor), pp.1-28. Oxford University Press.

Healy, J. M. 1996 Molluscan sperm ultrastructure: correlation with taxonomic units within the Gastropoda, Cephalopoda and Bivalvia. In Origin and evolutionary radiation of the Mollusca (ed. J. D. Taylor), pp. 99-114. Oxford University Press.

Heimler, W. 1987 Larvae. In The ultrastructure of Polychaeta (ed. W. Westheide \& C. O. Hermans), pp. 353-372. New York: Gustav Fischer.

Hendy, M. D. \& Penny, D. 1989 A framework for the quantitative study of evolutionary trees. Syst. Zool. 38, 297-309.

Hillis, D. M. \& Dixon, M. T. 1991 Ribosomal DNA: molecular evolution and phylogenetic inference. Q. Rev. Biol. 66, $411-446$.

Huelsenbeck, J. 1997 Is the Felsenstein zone a fly trap? Syst. Biol. 46, 69-74.

Jägersten, G. 1940 Zur Kenntnis der Morphologie, Entwicklung und Taxonomie der Myzostomida. Nova Acta R. Soc. Sci. Uppsala 11, 1-84.

Jangoux, M. 1990 Diseases of Echinodermata. In Diseases of marine animals (ed. O. Kinne), pp.439-467. Hamburg, Germany: Biologische Anstalt Helgoland.

Justine, J. L. 1995 Spermatozoal ultrastructure and phylogeny in the parasitic platyhelminthes. In Advances in spermatozoal phylogeny and taxonomy (ed. B. G. M. Jamieson, J. Ausio \& J. L. Justine), pp. 55-86. Paris: Mémoires du Muséum National d'Histoire Naturelle.

Kato, K. 1952 On the development of myzostomes. Sci. Rep. Saitama Univ. B 1, 1-16.

Kim, C. B., Moon, S. Y., Gelder, S. R. \& Kim, W. 1996 Phylogenetic relationships of annelids, molluscs and arthropods evidenced from molecules and morphology. 7. Mol. Evol. 43, 207-215.

Kishino, H. \& Hasegawa, M. 1989 Evaluation of the maximum likelihood estimate of the evolutionary tree topologies from DNA sequence data, and the branching order in Hominoidea. 7. Mol. Evol. 29, 170-179. 
Kobayashi, M., Wada, H. \& Satoh, N. 1996 Early evolution of the Metazoa and phylogenetic status of diploblasts as inferred from amino-acid sequence of elongation factor-1 $\alpha$. Mol. Phylogenet. Evol. 5, 414-422.

Kojima, J., Hashimoto, T., Hasegawa, M., Murata, S., Ohta, S., Seki, H. \& Okada, N. 1993 Close phylogenetic relationship between Vestimentifera (tube worms) and Annelida revealed by the amino acid sequence of elongation factor-lalpha. $\mathcal{F}$. Mol. Evol. 37, 66-70.

Kojima, S. 1998 Paraphyletic status of Polychaeta suggested by phylogenetic analysis based on the amino acid sequences of elongation factor 1-alpha. Mol. Biol. Evol. 9, 255-261.

Lecointre, G., Philippe, H., Vân Lê, H. L. \& Le Guyader, H. 1993 Species sampling has a major impact on phylogenetic inference. Mol. Phylogenet. Evol. 2, 205-224.

Leuckart, F. S. 1827 Versuch einer naturgemässen Eintheilung der Helminthen. In Neue Akademische Buchhandlung von Karl Gross, pp. 1-88. Heidelberg, Leipzig, Germany.

Leuckart, F. S. 1830 Untitled paragraphe no. 92. Isis von Oken 23, 612-613.

Leuckart, F. S. 1836 In Beziehung auf der Haarstern (Comatula) und Pentacrinus europaeus, so wie auf das Schmarotzerthier auf Comatula. Notiz. Gebiete Natur- und Heilk. Gesammelt Mitgetheilt Froriep 59, 129-131.

Lockhart, P. J., Steel, M. A., Hendy, M. D. \& Penny, D. 1994 Recovering evolutionary trees under a more realistic model of sequence evolution. Mol. Biol. Evol. 12, 503-513.

Lockhart, P. J., Steel, M. A., Barbrook, A. C., Huson, D. H., Charleston, M. A. \& Howe, C. J. 1998 A covariotide model explains apparent phylogenetic structure of oxygenic photosynthetic lineages. Mol. Biol. Evol. 15, 1183-1188.

McHugh, D. 1998 Deciphering metazoan phylogeny: the need for additional molecular data. Am. Zool. 38, 859-866.

Mackey, L. Y., Winnepenninckx, B., De wachter, R., Backeljau, T., Emschermann, P. \& Garey, J. R. 1996 18S rRNA suggests that entoprocta are protostomes, unrelated to ectoprocta. $\mathcal{F}$. Mol. Evol. 42, 552-559.

Maddison, W. P. \& Maddison, D. R. 1992 MacClade: analysis of phylogeny and character evolution. Sunderland, MA: Sinauer.

Mattei, X. \& Marchand, B. 1987 Les spermatozoïdes des acanthocephales et des myzostomides. Ressemblances et conséquences phylétiques. CR Acad. Sci. Paris 305, 525-529.

Meyer, D. L. \& Ausich, W. 1983 Biotic interactions among recent and among fossil crinoids. In Biotic interactions in recent and fossil benthic communities (ed. M. J. S. Tevesz \& P. L. McCall), pp. 377-427. New York: Plenum.

Milinkovitch, M. C. \& Lyons-Weiler, J. 1998 Finding optimal ingroup topologies and convexities when the choice of outgroups is not obvious. Mol. Phylogenet. Evol. 9, 348-357.

Milinkovitch, M. G., LeDuc, R. G., Adachi, J., Farnir, F., Georges, M. \& Hasegawa, M. 1996 Effects of character weighting and species sampling on phylogeny reconstruction: a case study based on DNA sequence data in cetaceans. Genetics 144, 1817-1833.

Omland, K. E. 1999 The assumptions and challenges of ancestral state reconstruction. Syst. Biol. 48, 604-611.

Pietsch, A. \& Westheide, W. 1987 Protonephridial organs in Myzostoma cirriferum (Myzostomida). Acta Zool. 68, 195-203.
Rambaut, A. \& Grassly, N. C. 1997 Seq-Gen: an application for the Monte Carlo simulation of DNA sequence evolution along phylogenetic trees. Comput. Appl. Biosci. 13, 235-238.

Rouse, G. W. \& Fauchald, K. 1997 Cladistics and polychaetes. Zool. Scripta 26, 139-204.

Semper, C. 1858 Zur Anatomie und Entwickelungsgeschichte der Gattung Myzostoma Leuckart. Zeitschr. Wiss. Zool. 9, 48-65.

Specht, A. 1988 Chaetae. In The ultrastructure of Polychaeta (ed. W. Westheide \& C. O. Hermans), pp.45-59. New York: Gustav Fischer.

Swofford, D. 1999 PAUP : phylogenetic analysis using parsimony (and other methods), v. 4.0. Sunderland, MA: Sinauer Associates.

Swofford, D., Olsen, G., Waddell, P. \& Hillis, D. 1996 Phylogenetic inference. In Molecular systematics, 2nd edn (ed. D. Hillis, C. Moritz \& B. Mable), pp.407-514. Sunderland, MA: Sinauer Associates.

Tempelton, A. R. 1983 Phylogenetic inference from restriction endonuclease cleavage site maps with particular reference to the evolution of humans and apes. Evolution 37, 221-244.

Thompson, J. D., Higgins, D. G. \& Gibson, T. J. 1994 CLUSTAL W: improving the sensitivity of progressive multiple sequence alignment through sequence weighting, position-specific gap penalties and weight matrix choice. Nucl. Acids Res. 22, 4673-4680.

Van de Peer, Y., Robbrecht, E., De Hoog, S., Caers, A., De Rijk, P. \& De Wachter, R. 1999 Database on the structure of small subunit ribosomal RNA. Nucl. Acids Res. 27, 179-183.

Von Graff, L. 1884 Report on the Myzostomida collected during the voyage of HMS Challenger during the years 1873-1876. Rep. Sci. Res. HMS Chall. Exped. 10, 1-82.

Warn, J. M. 1974 Presumed myzostomid infestation of an Ordovician crinoid. 7. Paleontol. 48, 506-513.

Westheide, W. 1997 The direction of evolution within the Polychaeta 7. Nat. Hist. 31, 1-15.

Wheeler, W. C. 1990 Nucleic acid sequence phylogeny and random outgroups Cladistics 6, 363-367.

Winnepenninckx, B., Backeljau, T. \& De Wachter, R. 1995a Phylogeny of protostome worms derived from $18 \mathrm{~S}$ rRNA sequences. Mol. Biol. Evol. 12, 641-649.

Winnepenninckx, B., Backeljau, T., Mackey, L. Y., Brooks, J. M., De Wachter, R., Kumar, S. \& Garey, J. R. 1995b 18S rRNA data indicate that aschelminthes are polyphyletic in origin and consist of at least three distinct clades. Mol. Biol. Evol. 12, $1132-1137$.

Winnepenninckx, B., Backeljau, T. \& De Wachter, R. 1996 Investigation of molluscan phylogeny on the basis of $18 \mathrm{~S}$ rRNA sequences. Mol. Biol. Evol. 13, 1306-1317.

Winnepenninckx, B., Van de Peer, Y. \& Backeljau, T. 1998 Metazoan relationships on the basis of $18 \mathrm{~S}$ rRNA sequences: a few years later. Am. Zool. 38, 888-906.

Zrzavy, J., Mihulka, S., Kepka, P., Bezdek, A. \& Tietz, D. 1998 Phylogeny of the metazoa based on morphological and $18 \mathrm{~S}$ ribosomal DNA evidence. Cladistics 14, 249-285.

As this paper exceeds the maximum length normally permitted, the authors have agreed to contribute to production costs. 